\title{
Divergences in Hormonal and Enzymatic Antioxidant Responses of Two Chicory Ecotypes to SALT STREsS ${ }^{1}$
}

\author{
Divergências nas Respostas Hormonais e de Enzimas Antioxidantes de Dois Ecótipos de Chicória \\ ao Estresse Salino
}

GHANAATIAN, $\mathrm{K}^{2}$, and SADEGHI, $\mathrm{H}^{2}$

\begin{abstract}
Salinity is among the most common and severe abiotic stresses that drastically affects crop productivity all over the world. To evaluate the effect of salt stress on seed germination, early growth, antioxidant enzyme activity and ABA content of chicory ecotypes (Cichorium intybus), a factorial experiment was conducted at College of Agriculture, Shiraz University in 2014 based on completely randomized design with four replications. The treatments comprised five salinity levels (tap water, 3, 6, 9, $12 \mathrm{dS} \mathrm{m}^{-1}$ ) of sodium chloride on the ecotypes of Sefid Shiraz and Siyah Shiraz. The results showed that germination characteristics and primary seedling growth decreased in both ecotypes with increasing in salinity severity. The effects of salinity on radicle and plumule length as well as seedling weight were the same as its effects on seed germination. The effect of salt stress on antioxidant enzyme activity (especially catalase) and ABA content were significant which they were enhanced with increasing salinity level; the Siyah Shiraz ecotype performs better than the Sefid Shiraz under high salinity, as indicated by lower decrease in germination characteristics and primary growth and higher antioxidant enzyme activity as well as ABA content. These facts should be taken into consideration in the economic cultivation of this valuable horticultural and medicinal plant and this data would be useful for the crop breeding projects.
\end{abstract}

Keywords: salt stress, chicory ecotypes, germination characteristics, antioxidant enzyme activity.

RESUMO - A salinidade está entre os estresses abióticos mais comuns e graves que afetam severamente a produtividade das culturas em todo o mundo. Para avaliar o efeito do estresse salino na germinação das sementes, no crescimento inicial, na atividade de enzimas antioxidantes e no conteúdo de ABA de ecótipos de chicória (Cichorium intybus), um experimento fatorial foi realizado na Faculdade de Agricultura da Universidade de Shiraz em 2014, com base em um delineamento experimental inteiramente casualizado com quatro repetições. Os tratamentos incluíram cinco niveis

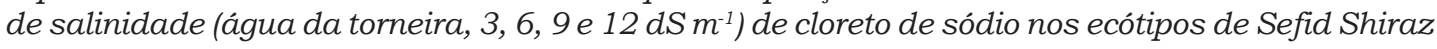
$e$ Siyah Shiraz. Os resultados mostraram que as características de germinação e o crescimento de plântulas primário diminuíram em ambos os ecótipos com o aumento da gravidade da salinidade. Os efeitos da salinidade sobre a radicula e o comprimento da plúmula, bem como sobre o peso de plântulas, foram os mesmos que aqueles sobre a germinação das sementes. Os efeitos do estresse salino sobre a atividade de enzimas antioxidantes (especialmente catalase) e o conteúdo de ABA foram significativos e reforçados com o aumento do nivel de salinidade; o ecótipo Siyah Shiraz teve desempenho melhor do que o Sefid Shiraz sob alta salinidade, indicado pela diminuição nas características de germinação e crescimento primário e pela maior atividade de enzimas antioxidantes, bem como pelo conteúdo de ABA. Esses fatos devem ser levados em consideração no cultivo dessa importante planta medicinal de horticultura, e esses dados serão úteis para projetos que buscam a melhoria dessas culturas.

Palavras-chave: estresse salino, ecótipos de chicória, características de germinação, atividade de enzimas antioxidantes.

1 Recebido para publicação em 8.9.2015 e aprovado em 23.10.2015.

2 Department of Natural Resources and Environmental Engineering, College of Agriculture, Shiraz University, Shiraz, Iran, <Sadeghih@shirazu.ac.ir>. 


\section{INTRODUCTION}

The areas with saline and alkaline soils are expanding, especially in arid and semiarid regions of Iran and cover 25 million hectares of this country's dry lands (Mosleh-Arany et al., 2011). It is widely accepted that an intricate network of plant hormones regulates every plant response to environmental stimuli. These hormonal interactions modulate the intensity of the physiological response to the stress pressure. Plants have developed different mechanisms to adapt to salinity stress, involving complex physiological and biochemical changes. In the process of stress adaptation, hormones, especially abscisic acid (ABA), play important roles (Amjad et al., 2014). It has been proposed that ABA acts as a mediator and major internal signal in plant response to abiotic stresses (Javid et al., 2011). ABA concentration increases proportionally with salt stress related to leaf water potential and its higher concentration can be due to water deficit created by salts rather than a specific salt effect (Davies et al., 2002; Lovelli et al., 2012). This higher ABA concentration reduces water loss as transpiration by the closure of stomata under stressful conditions (Zhang et al., 2006; Hariadi et al., 2011). In addition, ABA activates the expression of genes encoding antioxidant enzymes, increasing the activity of antioxidant enzymes including superoxide dismutase (SOD), catalase (CAT) and ascorbate peroxidase (APX) (Jiang \& Zhang, 2002; Yang et al., 2014). The increased capacity of reactive oxygen species (ROS) scavenging alleviates the damaging effect of ROS on fat/oil and protein (Hu et al., 2006). ABA also plays critical roles in reducing stomatal conductance and inducing the expression of genes responsible for various osmolytes synthesis, such as proline and betaine (Jung et al., 2008; Antoni et al., 2011).

Chicory is a plant species belonging to the Asteraceae family, is also known as blue sailors, endive, succory, coffee weed and Kasni (Persian) (Mosaddegh et al., 2012), and is native to the Mediterranean region, mid Asia and northern Africa. In olden times, chicory was grown by the ancient Egyptians as a medicinal plant, coffee substitute, vegetable crop, and occasionally for animal forage
(Munoz, 2004). Greeks and Romans also began to grow chicory as a vegetable crop 4000 years ago (Plmuier, 1972). Currently, chicory is cultivated widely in Europe, Lebanon, some Arab countries and North America with many commercial uses (Wang \& Cui, 2011). Chicory is one of the earliest known and most widely used raw materials for manufacturing of coffee substitutes (Pazola, 1987). The fresh leaves can be used as salad as they are rich in vitamin $\mathrm{A}$ and $\mathrm{C}$ and also micronutrients (Bremness, 1998). Aerial parts of chicory are utilized in preparation of meals and salads, while the root is used as a chewing gum. The plant is also used as a sunscreen replacement. Multiple research papers have been published describing the phytochemical composition and several health properties of $C$. intybus, including antidiabetic, wound healing and antioxidant capacities of chicory grown in various European countries (Spina et al., 2008; Azay-Milhau et al., 2013; Carazzone et al., 2013; Morales et al., 2014).

Although some recent reports have demonstrated the effects of salinity on germination and physiological parameters in C. intybus seedlings (Arshi et al., 2006, 2010; Sergio et al., 2012), there is a remaining information gap related to hormonal response in chicory under salinity and an integrative study of germination, primary seedling development, antioxidant enzyme activity and ABA response under salinity in this species has not been performed. Moreover, C. intybus displays a high level of variability both between and within populations due to its natural polymorphism (Arshi et al., 2006, 2010). In this context, our aim was to evaluate the stress-induced salt changes in germination components, growth, antioxidant enzyme activity and ABA concentration in two chicory ecotypes.

\section{MATERIAL AND METHODS}

\section{Study site and Plant materials}

This study has been carried out in a controlled environment (growth chamber) of the laboratory at the College of Agriculture, Shiraz University, Shiraz, Iran [52 $2^{\circ} 46^{\prime}$ E, 29 $9^{\circ} 50^{\prime}$ $\mathrm{N}$, altitude $1,810 \mathrm{~m}$ asl, $12 \mathrm{~km}$ north of the city of Shiraz during 2010. Uniform and 
healthy seeds of two chicory () ecotypes including Shiraz white ecotype (white ecotype) and Shiraz black ecotype (black ecotype), were procured from Pakan Bazr Co. (Isfahan, Iran) and stored at $4{ }^{\circ} \mathrm{C}$ till the study was undertaken.

\section{Experminetal}

Chicory seeds were surface sterilized with $5 \%$ sodium hypochlorite, then seeds were washed twice with distilled water. 20 seeds were placed in each 9 -cm glass petri dish on two layers of filter paper (Whatman No. 2). The petri dishes were placed in a germinator at $25 \pm 2{ }^{\circ} \mathrm{C}$ and were irrigated with 4 different $\mathrm{NaCl}$ solutions $\left(3,6,9,12 \mathrm{dS} \mathrm{m}^{-1}\right)$ and tap water $\left(0.62 \mathrm{dS} \mathrm{m}^{-1}\right)$ was used as control (Sergio et al., 2012). Seed germination was recorded daily up to day 20 after the beginning of the experiment. Seeds were considered germinated when radical emerged by about $2 \mathrm{~mm}$ in length. According to the daily germination percentage data, germination rate (GR) was calculated based on the following formula (Mohammadi, 2009):

$$
G R=\frac{\sum n}{D n}
$$

where $G R$ is the germination rate, $n$ is the number of seeds germinated on a specific day, and $D$ is the number of days from the start of experiment. Germination percentage was determined at the end of the experiment, based on the following formula (Bajehbaj, 2010):

$$
\operatorname{Ger} \%=\frac{n}{N}
$$

where Ger\% is germination percentage, $n$ is number of seeds germinated, and $N$ is total number of seeds planted. Radicle length, plumule length, seedling weight and antioxidant enzyme activities were measured at the end of the experiment. In each recording, 10 seedlings were randomly selected from each petri dish, and their averages were considered as sample data.

ABA concentration was measured on white ecotype and black ecotype chicory plants. Briefly, five-week-old plants of both ecotypes grown hydroponically with one-fifth Johnson's solution supplemented with $10 \mathrm{mM}$ Fe-EDDHA were transferred either to a new nutrient solution with $\mathrm{NaCl}\left(3,6,9,12 \mathrm{dS} \mathrm{m}^{-1}\right)$ for salt stress or to a nutrient solution without salt as the control (Yang et al., 2014). Fifteen days after salt treatment, youngest fully expanded leaves were sampled to determine ABA concentration as described in Lovelli et al. (2012).

\section{Activities of antioxidant enzymes}

At the end of the experiment, antioxidant enzyme activities were measured. Fresh leaf tissues $(500 \mathrm{mg})$ were titrated in $10 \mathrm{~mL}$ phosphate buffer [pH 7.8;50 mM] using an ice cooled sterilized pestle and mortar. The extract was centrifuged at $15,000 \times \mathrm{g}$ for $15 \mathrm{~min}$ at $4{ }^{\circ} \mathrm{C}$. The supernatant was separated in another autoclaved eppendorf tubes and used for determining the activities of enzymes, superoxide dismutase (SOD), peroxidase (POD) and catalase (CAT). Inhibition in photoreduction of nitroblue tetrazolium (NBT) was used to appraise the activity of SOD. The reaction mixture $(1 \mathrm{~mL})$ [500 $\mu \mathrm{L}$ phosphate buffer $(\mathrm{pH} 7.8), 0.5 \mathrm{~mL}$ distilled $\mathrm{H}_{2} \mathrm{O}, 100 \mu \mathrm{L}$ methionine, $50 \mu \mathrm{L}$ NBT and $50 \mu \mathrm{L}$ sample extract] in cuvettes was kept under light for $20 \mathrm{~min}$. The optical density of the irradiated aliquot was read at $560 \mathrm{~nm}$. Following, Giannopolitis \& Ries (1977), SOD enzyme activity per unit was based on the amount of enzyme that inhibited $50 \%$ of NBT photoreduction. The method of Chance \& Maehly (1955) was used for appraising CAT and POD activities. HEPES buffer $(25 \mathrm{mM}$, pH 7.8) containing $0.2 \mathrm{mM}$ EDTA, $2 \%$ PVP and 2 $\mathrm{mM}$ ascorbate was used for APX (EC 1.11.1.11) extraction. Enzyme activity was determined according to Zhu et al. (2004) protocol. The activities of all four enzymes were expressed as $\mathrm{U} \mathrm{mg}^{-1}$ protein.

\section{ABA measurement}

An aliquot of $250 \mathrm{mg}$ of leave tissue was ground into powder with liquid nitrogen with a mortar and pestle, and put in a tube. $2.5 \mathrm{~mL}$ extraction solvent (2-propanol/ $\mathrm{H}_{2} \mathrm{O} / \mathrm{HCl} 37 \%$; $2: 1: 0.002, \mathrm{v} / \mathrm{v} / \mathrm{v}$ ) was added to each tube. The tubes were shaken at a speed of $100 \mathrm{rpm}$ for 
$30 \mathrm{~min}$ at $4{ }^{\circ} \mathrm{C} .2 .5 \mathrm{~mL}$ of dichloromethane was added to each tube, and then the samples were shaken for $30 \mathrm{~min}$ at $4{ }^{\circ} \mathrm{C}$ and centrifuged at $13,000 \times \mathrm{g}$ for $5 \mathrm{~min}$. After centrifugation, two phases were formed, with plant debris between the two layers; thus, $1.0 \mathrm{~mL}$ of the solvent from the lower phase was transferred using a Pasteur pipette into a screw-cap vial, and the solvent mixture was concentrated using an evaporator with nitrogen flow. Finally, the samples were re-dissolved in $0.1 \mathrm{~mL}$ methanol and stored at $-20{ }^{\circ} \mathrm{C}$ before quantitative analysis. The quantitative determinations of abscisic acid (ABA) were carried out by a competitive enzyme linked immunosorbent assay (ELISA) using the Phytodetek ${ }^{\circledR}$ ABA Test Kit (Agdia Biofords, Evry, France) (Quarrie et al., 1988).

\section{Statistical analysis}

This study was carried out as a factorial experiment based on completely randomized design (CRD) with four replications with standard error using SAS12 software (SAS, 2004). The first factor was salt stress with $4 \mathrm{NaCl}$ level $\left(3,6,9,12 \mathrm{dS} \mathrm{m}^{-1}\right)$. Different ecotypes were the second factor including white ecotype and black ecotype. Fisher's Least Significant Difference (LSD) was used to separate means.

\section{RESULTS AND DISCUSSION}

\section{Germination and primary seedling growth}

For both chicory ecotypes, germination rate and germination percentage decreased progressively as the level of salinity increased (Figure 1). However, there was no significant ifference between tap water, 3 and $6 \mathrm{dS} \mathrm{m}^{-1}$ in the for germination percentage. Germination rate decreased with increasing salinity level, with no significant differences between salinity levels (Figure 1). Salt stress significantly reduced the growth of $C$. intybus seedlings (Figure 2). The radicle length differed significantly only between tap water and $3 \mathrm{dS} \mathrm{m}^{-1}$ in Sefid Shiraz ecotype, but the difference $3 \mathrm{dS} \mathrm{m}^{-1}$ and other salinity levels were not significant. The similar decreasing trend was found in Siyah Shiraz ecotype, with no significant difference. Radicle length

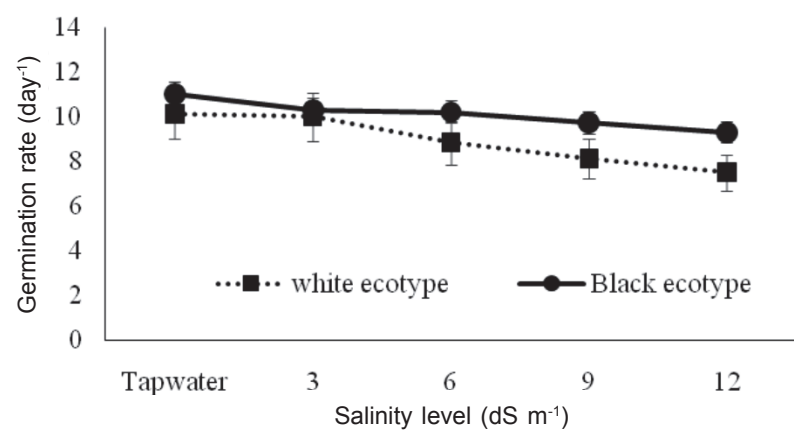

Figure 1 - Effect of salinity on seed germination percentage (\%) and rate of two chicory ecotypes. The means with the similar overlap had no significant difference $( \pm S E)$. Tap water $\left(0.62 \mathrm{dS} \mathrm{m}^{-1}\right)$.
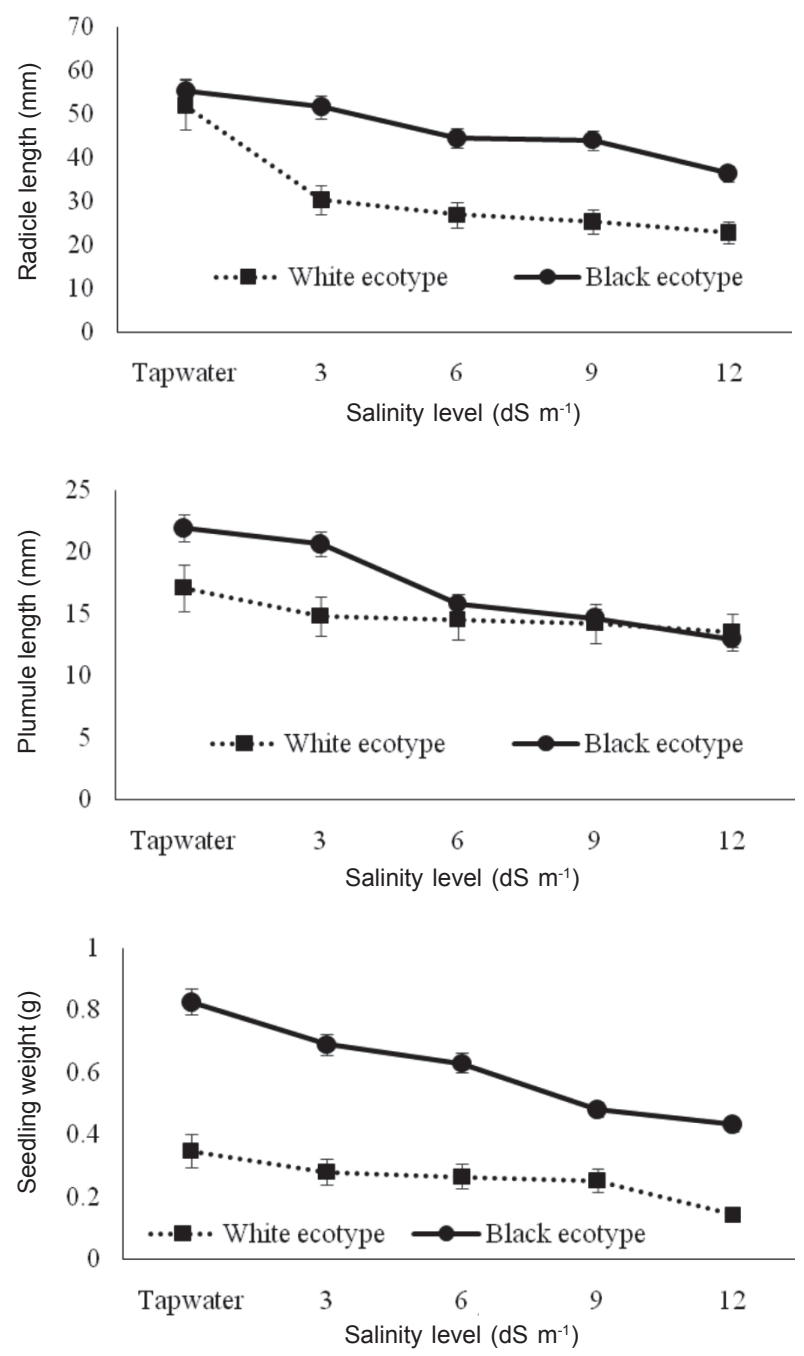

Figure 2 - Effect of salinity on radicle length, plumule length and seedling weight of two chicory ecotypes. The means with the similar overlap had no significant difference $( \pm \mathrm{SE})$. Tap water $\left(0.62 \mathrm{dS} \mathrm{m}^{-1}\right)$. 
increased between 6 to $9 \mathrm{dS} \mathrm{m}^{-1}$ in Siyah Shiraz ecotype with no significant difference. Decreasing the plumule length with increasing salinity level was only significant between 3 and $6 \mathrm{dS} \mathrm{m}^{-1}$. This decreasing trend in plumule length wasn't significant in Sefid Shiraz ecotype. Seedling weight significantly decreased with increasing salt concentration, in Siyah Shiraz ecotype, whereas in Sefid Shiraz ecotype, any significant difference wasn't found between the different levels of salinity. Moreover, seedling weight was consistent at 3, 6 and $9 \mathrm{dS} \mathrm{m}^{-1}$.

\section{Antioxidant enzyme activity}

CAT activity significantly increased with increasing salinity level in both ecotypes (Figure 3). However, in Sefid Shiraz ecotype, this increasing trend wasn't significant between tap water, 3 and $6 \mathrm{dS} \mathrm{m}^{-1}$ salinity levels (Figure 3). In Sefid Shiraz ecotype, the activity of POD had no significant
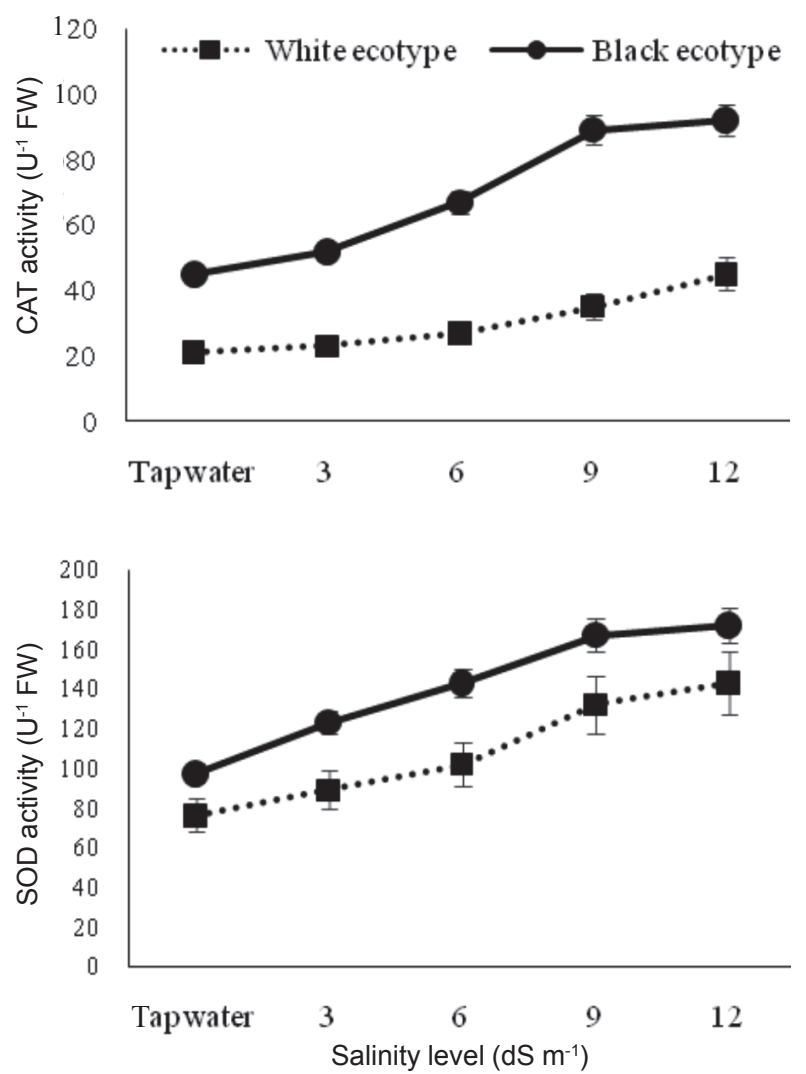

increase, while in Siyah Shiraz ecotype, salinity increased POD activity up to $6 \mathrm{dS} \mathrm{m}^{-1}$, remained constant from 6 to $9 \mathrm{dS} \mathrm{m}^{-1}$ and reduced from 9 to $12 \mathrm{dS} \mathrm{m}^{-1}$ (Figure 3 ). SOD activity increased significantly by increasing salinity in both ecotypes. Similar to SOD, APX activity increased with salt stress in both ecotypes, although in Sefid Shiraz ecotype this difference was insignificant (Figure 3).

\section{Abscisic acid}

Salinity induces ABA accumulation in both ecotype leaves (Figure 4). ABA concentration slightly increased up to $6 \mathrm{dS} \mathrm{m}^{-1}$ in both ecotypes and the quantity of $\mathrm{ABA}$ was equal more or less in both ecotypes, while, ABA concentration significantly increased with more severe treatments (6 to $12 \mathrm{dS} \mathrm{m}^{-1}$ ). Also the ABA accumulation in Siyah Shiraz ecotype was significantly higher than the Sefid Shiraz one (Figure 4).
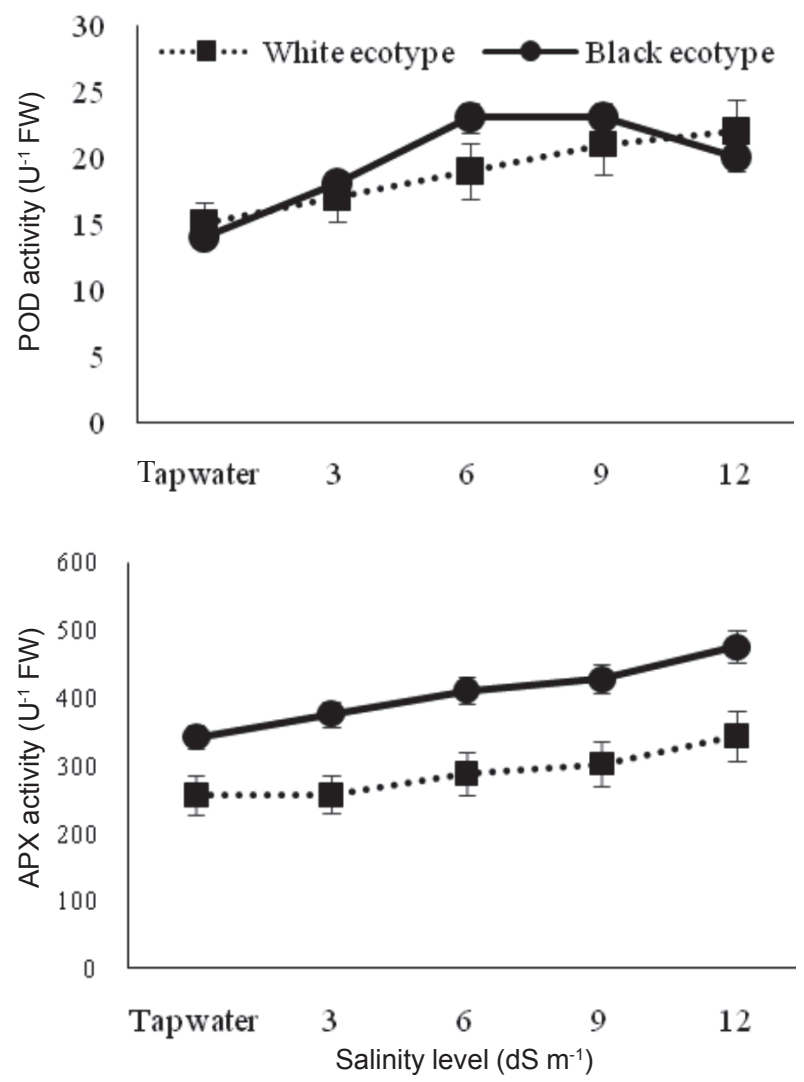

Figure 3 - Effect of salinity on catalase (CAT), peroxidase (POD), superoxide dismutase (SOD) and ascorbic peroxidase (APX) activity of two chicory ecotypes. The means with the similar overlap had no significant difference $( \pm \mathrm{SE})$. Tap water $\left(0.62 \mathrm{dS} \mathrm{m}^{-1}\right)$. 


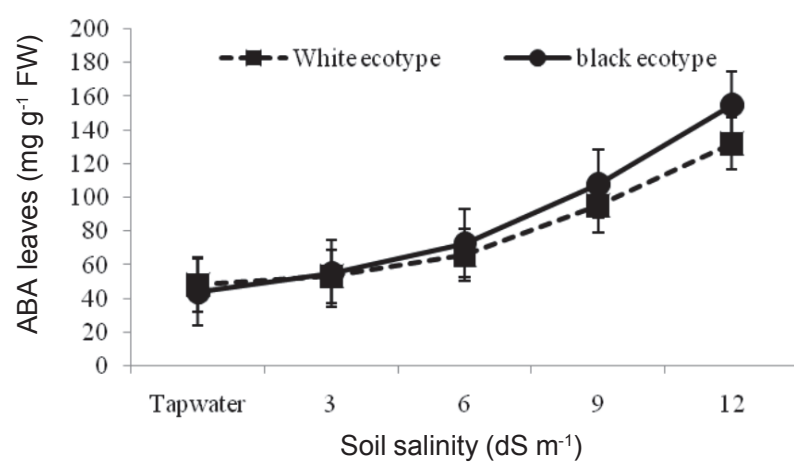

Figure 4 - Leaves ABA concentration of chicory ecotypes in response to increasing salinity level of the nutrient solution. The means with the similar overlap had no significant difference $( \pm \mathrm{SE})$. Tap water $\left(0.62 \mathrm{dS} \mathrm{m}^{-1}\right)$.

The germination percentage and rate of C. intybus seeds decreased and was delayed in the presence of $\mathrm{NaCl}$, and significantly affected

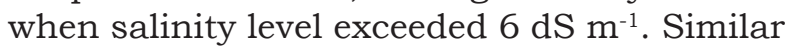
results were obtained in Sergio et al. (2012), Arshi et al. $(2006,2010)$ studies. They found that the salt stress declined the germination and also delayed the emergence of chicory seeds although Sergio et al. (2012) reported wild chicory seeds were well capable of germinating in saline conditions.

The radicle and plumule lengths were inhibited by salinity stress (Figure 2). The radicle length showed greater reduction than plumule in both ecotypes, while decrease under higher salinity levels was more or less equal in both Siyah Shiraz and Sefid Shiraz ecotypes. Salt stress inhibits the efficiency of the translocation and assimilation of photosynthetic products (Mohammadi, 2009) and might have caused reduction in shoot growth. Reduction in plant growth has also been attributed to reduced water absorption due to osmotic effect, nutritional deficiency on account of ionic imbalance and decrease in many metabolic activities (Hariadi et al., 2011; Lovelli et al., 2012). Greater influence of salinity on radicle length than plumule has also been shown by Sehrawat et al. (2014) in mungbean (Vigna radiata). Reduction of root biomass may be due to inhibition of hypocotyls growth led by salt treatments (Atia et al., 2009). Seedlings of the control culture had greater fresh weight than those of the salinity treatments (Figure 2), reported by Sergio et al. (2012) and Arshi et al. (2006) who studied the response of $C$. intybus seedlings to salinity.

According to the Figure 1 and 2, black ecotype showed higher germination characteristics and performance under salt stress. Salt tolerance varies widely among plant species and varieties, but is, generally dependent on the controlled uptake and compartmentalization of ions such $\mathrm{Na}^{+}, \mathrm{K}^{+}$and $\mathrm{Cl}^{-}$(Zhu, 2001). Maintaining a low $\mathrm{Na}+/ \mathrm{K}+$ ratio in the cytosol is an important salt-tolerance strategy in plants (Bajehbaj, 2010). The differences between chicory ecotypes might be due to the genetic factors and heredity variations (Sergio et al., 2012).

Increased activity of antioxidant enzymes of salt tolerant ecotypes in response to salt stress imply that ROS-scavenging might be a part of the general adaptive strategy of plants exposed to salinity (Zhu et al., 2004). In the present investigation, the activity of antioxidant enzymes (except for POD) showed a progressive increase in both ecotypes (especially the Siyah Shiraz) at all salt concentrations (Figure 3). Increase in activity of SOD, APX and CAT in response to salinity stress as well as higher antioxidant activity in tolerant species/varieties have also been reported by various researchers (Sergio et al., 2012; Yang et al., 2014). These findings also strongly imply a possibility that antioxidant enzyme systems are also utilized in C. intybus to lessen oxidative stress caused by salinity, thus protecting the cells from oxidative damage (Zhu et al., 2004). The increased activity of the antioxidant enzymes upon salt stress is often related to the enhanced tolerance to salt stress (Zhu et al., 2004). Furthermore, each enzyme showed specific quantitative and qualitative responses under salt stress. A rapid and continued increase in CAT and SOD activity might indicate that CAT and SOD are major enzymes detoxifying hydrogen peroxide in chicory ecotypes under salt stress. At higher levels of salt, the activity of SOD was significantly the highest by almost twofold when compared to control (Figure 4). The changes in APX, SOD and CAT activities were consistent with the previous reports (Sergio et al., 2012; Yang et al., 2014). The basal level of all of antioxidant enzyme activities was also significantly higher in 
salt-tolerant (the Siyah Shiraz one) than in Sefid Shiraz ecotype. These findings agree with those reported for potatoe (Solanum tuberosum) (Benavides et al., 2000), where tolerant-cultivars had higher basal level of enzyme activity compared to sensitive ones.

Concerning to abscisic acid, many reports have shown its involvement on physiological and biochemical processes related to salinity tolerance of plants (Lovelli et al., 2012; Amjad et al., 2014). ABA played important roles in abiotic stress in chicory. Under salt stress, ABA levels increased dramatically with increased salinity in chicory ecotypes leaves (Figure 4), suggesting that ABA acts as a signal in salt response. ABA controls many stress adaptation responses, including stomatal closure, activation of genes involved in osmotic adjustment, ion compartimentation, regulation of shoot versus root growth and modifications of root hydraulic conductivity properties (Jiang et al., 2002; Zhang et al., 2006; Hu et al., 2006; Antoni et al., 2011; Javid et al., 2011). Regardless of the absolute amount of ABA, the slope shift observed at $6 \mathrm{dS} \mathrm{m}^{-1}$ for both ecotypes versus salinity is noticeable and this was more pronounced in
Siyah Shiraz ecotype than Sefid Shiraz one. These results are consistent with those of Yang et al. (2014) and Lovelli et al. (2012) in tomato (Solanum lycopersicum) and $\mathrm{Hu}$ et al. (2006) in maize (Zea mays), who reported that salt tolerant plants contain more ABA concentration than sensitive ones. In addition, ABA activates the expression of genes encoding antioxidant enzymes, increasing the activity of antioxidant enzymes including superoxide dismutase (SOD), catalase (CAT) and ascorbate peroxidase (APX) (Yang et al., 2014). The increased capacity of reactive oxygen species (ROS) scavenging alleviates the damaging effect of ROS on fat/oil and protein (Zhu et al., 2004).

In summary, $C$. intybus showed salt tolerance at germination and seedling growth stage at low level of salinity ( 3 and $6 \mathrm{dS} \mathrm{m}^{-1}$ ). Increasing salinity lowered the germination percentage and primary seedling growth in both ecotypes. However, the Siyah Shiraz ecotype performs better than Sefid Shiraz under high salinity, as indicated by a lower decrease in germination characteristics and primary growth and higher antioxidant enzyme activity. These facts should be taken
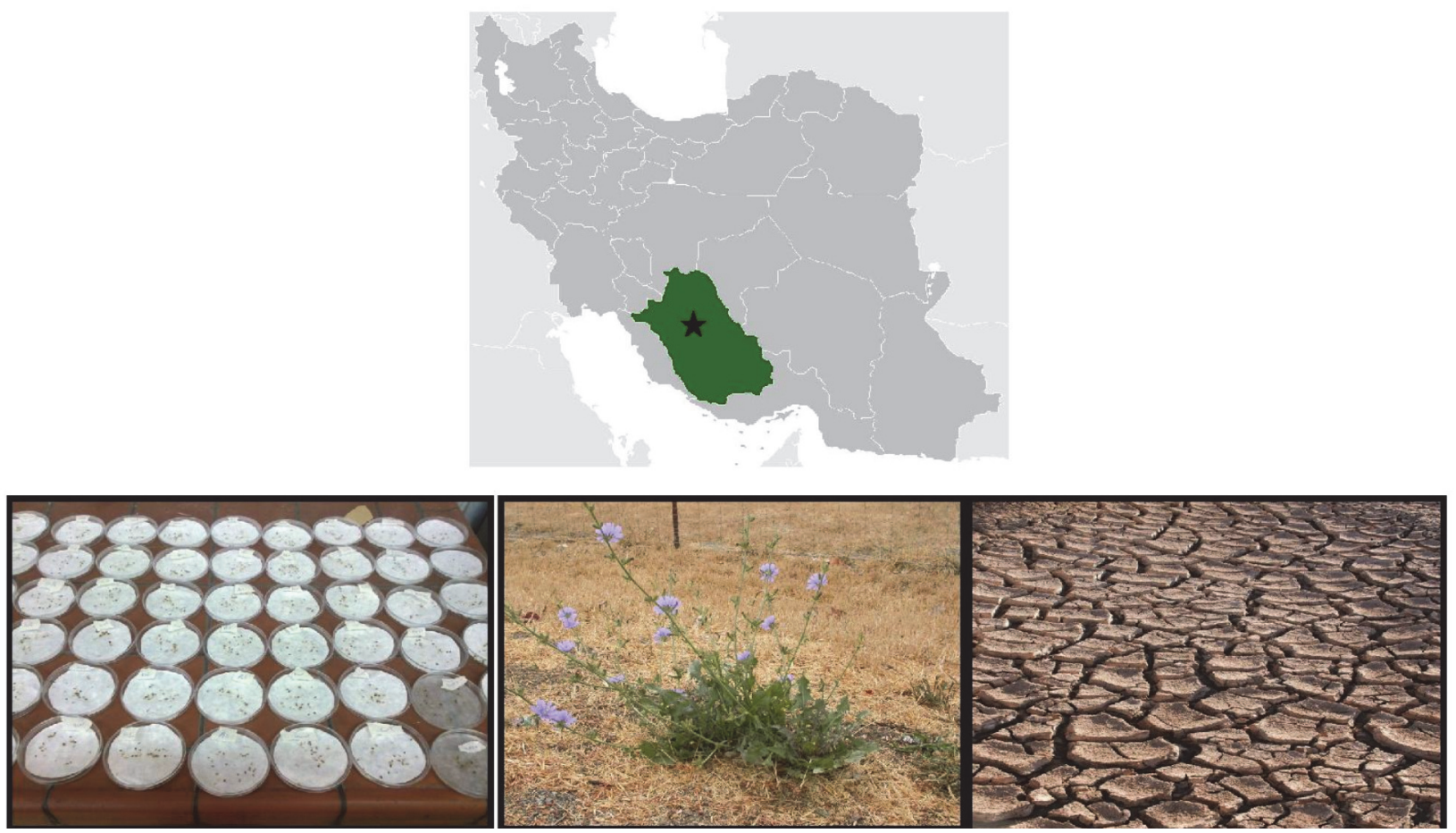

Figure 5 - Graphical abstract (study site, experimental materials and chicory). 
into consideration in the cultivation of this valuable horticultural and medicinal plant and this data would be useful for crop breeding projects. Increases in antioxidant enzyme activities (especially CAT) of chicory as well as endogenous ABA content occur with increasing salinity level. Yet ABA increases from a certain threshold on salt stress levels. Since ABA is involved in the activation of many stress adaptation responses, this threshold may identify a physiological trigger that characterizes a transition from molecular/cellular adaptation to more complex structural/morphological modifications. The physiological significance of this shift requires further investigation.

\section{ACKNOWLEDGMENTS}

We would like to express our special thanks to the Department of Natural Resources and Environmental engineering, the College of Agriculture, the Shiraz University, for their financial support to the development of this present study.

\section{LITERATURE CITED}

AMJAD, M. et al. Integrating role of ethylene and ABA in tomato plants adaptation to salt stress. Sci Hortic., v. 172, n. 6, p. 109-116, 2014.

ANTONI, R. et al. News on ABA transport, protein degradation, and ABFs/WRKYs in ABA signaling. Curr. Opin. Plant Biol., v. 14, n. 5, p. 547-553, 2011.

ARSHI A. et al. Effect of calcium against salinity-induced inhibition in growth, ion accumulation and proline contents in Cichorium intybus L. J. Environ. Biol., v. 31, n. 6, p. 939-944, 2010.

ARSHI, A. et al. Effect of $\mathrm{CaCl} 2$ on growth performance, photosynthetic efficiency and nitrogen assimilation of Cichorium intybus L. grown under $\mathrm{NaCl}$ stress. Acta Physiol. Planta, v. 28, n. 2, p. 137-147, 2006.

ATIA, A. et al. Interactive effects of salinity, nitrate, light, and seed weight on the germination of the halophyte Crithmum maritimum. Acta Biol Hung, v. 60, n. 4, p. 433-439, 2009.

AZAY-MILHAU, J. et al. Anti-hyperglycemic effect of a natural cichoric acid extract of chicory (Cichorium intybus L.): A comparative in vitro study with the effects of caffeic and ferulic acids. J. Ethnopharmacol., v. 150, n. 2, p. 755-760, 2013.

Planta Daninha, Viçosa-MG, v. 34, n. 2, p. 199-207, 2016
BAJEHBAJ, A. A. The effects of $\mathrm{NaCl}$ priming on salt tolerance in sunflower germination and seedling grown under salinity conditions. Afr. J. Biotechnol., v. 12, n. 9, p. 1764-1770, 2010.

BENAVIDES M. P. et al. Relationship between antioxidant defence systems and salt tolerance in Solanum tuberosum. Aust. J. Plant Physiol., v. 27, n. 4, p. 273-278, 2000.

BREMNESS, L. London: dorling kindersley. In: CHISHOLM, J. (Ed.). The complete book of herbs. London: Dorling Kindersley, 1998. 288 p.

CARAZZONE, C. et al. Identification of phenolic constituents in red chicory salads (Cichorium intybus) by high-performance liquid chromatography with diode array detection and electrospray ionizationtandem mass spectrometry. Food Chem., v. 138, n. 3, p. 1062-1071, 2013.

CHANCE, M.; MAEHLY, A. C. Assay of catalases and peroxidases. Methods Enzymol., v. 2, n. 2, p. 764-817, 1955.

DAVIES, W. J.; WILKINSON, S.; LOVEYS, B. Stomatal control by chemical signaling and the exploitation of this mechanism to increase water use efficiency in agriculture. New Phytol., v. 153, n. 3, p. 449-460, 2002.

GIANNOPOLITIS, C. N.; RIES, S. K. Superoxide dismutase. I. Occurrence in higher plants. Plant Physiol., v. 59, n. 2, p. 309-314, 1977.

HARIADI, Y. et al. Ionic and osmotic relations in quinoa (Chenopodium quinoa Willd.) plants grown at various salinity levels. J. Exper. Bot., v. 62, n. 2, p. 185-193, 2011.

HU, X. L. et al. Calcium calmodulin is required for abscisic acid-induced antioxidant defense and functions both upstream and downstream of $\mathrm{H}_{2} \mathrm{O}_{2}$ production in leaves of maize ( $\mathrm{Zea}$ mays) plants. New Phytol., v. 173, n. 1, p. 27-38, 2006.

JAVID, M. G. et al. The role of phytohormones in alleviating salt stress in crop plants. Austr. J. Crop Sci., v. 5, n. 5, p. 726-734, 2011.

JIANG, M.; ZHANG, J. Role of abscisic acid in water stressinduced antioxidant defense in leaves of maize seedlings. Free Radic. Res., v. 36, n. 6, p. 1001-1015, 2002.

JUNG, C. et al. Overexpression of AtMYB44 enhances stomatal closure to confer abiotic stress tolerance in transgenic Arabidopsis. Plant Physiol., v. 146, n. 2, p. 623-635, 2008.

LOVELLI, S. et al. Abscisic acid root and leaf concentration in relation to biomass partitioning in salinized tomato plants.

J. Plant Physiol., v. 169, n. 5, p. 226-233, 2012. 
MOHAMMADI G. R. The influence of $\mathrm{NaCl}$ priming on seed germination and seedling growth of canola (Brassica napus L.) under salinity conditions. Am. Eur. Agric. Environ. Sci., v. 5, n. 5, p. 696-700, 2009.

MORALES, P. et al. Mediterranean -cultivated vegetables as dietary sources of compounds with antioxidantand biological activity. LWT-Food Sci. Technol., v. 55, n. 1, p. 389-396, 2014.

MOSADDEGH, M. et al. Ethnobotanical survey of herbal remedies traditionally used in Kohghiluyeh va Boyer Ahmad province of Iran. J. Ethnopharmacol., v. 141, n. 1, p. 80-95, 2012.

MOSLEH-ARANY, A. et al. Investigation on the effect of salinity stress on seed germination of Salsola abarghuensis, Salsola arbuscula and Salsola yazdiana. Iranian J.

Rangelands For. Plant Breed. Genetic Res., v. 18, n. 2, p. 267-279, 2011.

MUNOZ, C. L. M. Spanish medicinal Plants: Cichorium intybus L. B. R. Soc. Esp. His. Nat., v. 99, n. 1, p. 41-47, 2004.

PAZOLA, Z. The chemistry of chicory and chicory-product beverages. In: CLARKE, R. J.; MACRAE, R. (Ed.). Coffee related beverages. New York: Elsevier Applied Science Publishers, 1987. p. 19-57.

PLMUIER, W. Chicory improvement. R. Agric., v. 4, n. 8, p. $567-585,1972$.

QUARRIE S. A. et al. A monoclonal antibody to (S)-abscisic acid: its characterization and use in radioimmunoassay for measuring abscisic acid in crude extracts of cereal and lupin leaves. Planta, v. 173, n. 1, p. 130-139, 1988.
SAS Institute Inc. SAS/STAT 9.1 User's guide. Cary: 2004. $5136 \mathrm{p}$.

SEHRAWAT N, et al. Evaluation of mungbean genotypes for salt tolerance at early seedling growth stage. Biocatal Agric. Biotechnol., v. 3, n. 4, p. 108-113, 2014.

SERGIO, L. et al. Effect of salt stress on growth parameters, enzymatic antioxidant system, and lipid peroxidation in wild chicory (Cichorium intybus L.). Acta Physiol. Plant., v. 34, n. 5, p. 2349-2358, 2012.

SPINA, M. et al. Comparative evaluation of flavonoid content in assessing quality of wild and cultivated vegetables for human consumption. J. Sci. Food Agric., v. 88, n. 4, p. 294-304, 2008.

WANG, Q.; CUI, J. Perspectives and utilization technologies of chicory (Cichorium intybus L.): a review. Afr. J.

Biotechnol., v. 10, n. 11, p. 1966-1977, 2011.

YANG, R. et al. Hormone profiling and transcription analysis reveal a major role of ABA in tomato salt tolerance. Plant Physiol. Biochem., v. 77, n. 1, p. 23-34, 2014.

ZHANG et al. Role of ABA in integrating plant responses to drought and salt stresses. Field Crops Res., v. 97, n. 1, p. 111-119, 2006.

ZHU, J.-K. Plant salt tolerance. Trends Plant Sci., v. 6, n. 2, p. 66-71, 2001.

ZHU, Z. et al. Silicon alleviates salt stress and increases antioxidant enzyme activity in leaves of salt-stressed cucumber (Cucumis sativus L). Plant Sci., v. 167, n. 6, p. 527-533, 2004. 